\title{
Comparative Responses of Two Protozoa to Two Types of Radiation
}

Although protozoa are convenient for studying radiobiological effects at the cellular level, much remains unknown about their responses to radiation. Recent evidence indicates that the repair mechanisms of amoebae induced by ionizing radiation and UV-light reside in the same part of the cy toplasm ${ }^{1,2}$. Other workers have claimed that the repair mechanisms of Micrococcus radiodurans after exposure to UV-light or ionizing radiation are the same $^{3}$. If it is supposed that there is a $1: 1$ correspondence between repair mechanism and radiation induced lesion, it might be suggested that UV-light and ionizing radiation act in the same manner. We report experiments to test this unlikely hypothesis and show it to be untrue.

The method was to take 2 closely related protozoa", Actinophrys sol and Actinosphaerium moleofilum and examine the ratio of their relative resistances to the 2 different types of radiation. The source of UV-light was the unfiltered output of a Hanovia 'Chromatolite' lamp which is $84 \%$ on the $2534 \AA$ line, most of the remainder being in the visible blue. Dose rate at the standard position of irradiation was $52 \mathrm{ergs} \mathrm{mm}^{-2} \mathrm{sec}^{-1}$. Ionizing radiation was provided by a 100 Curie cobalt ${ }^{60}$ rod. Specimens were rotated parallel to and $4.8 \mathrm{~cm}$ distant from the rod. Standard dose rate was $580 \mathrm{r} \mathrm{min}^{-1}$. Cells to be irradiated were taken from cultures 3 weeks old, which were aerated and starved for 3 days before use. Single cells were pipetted from the culture and irradiated for appropriate periods. Precautions were taken to minimize any photo-reversal of latent lesions ${ }^{5}$, although in preliminary experiments no such effect was discovered. After exposure, the single cell cultures were supplied with food and stored in the dark. Temperature throughout the whole experiment was maintained at $20^{\circ} \mathrm{C}$. For all doses reported, between 90 and 450 cells were used. Irradiated cells were examined at regular intervals and, if necessary, supplied with food. All mortalities resulting from irradiation occurred before the second cell division after exposure and so if an irradiated cell were able to produce 4 offspring it was defined as surviving the treatment.
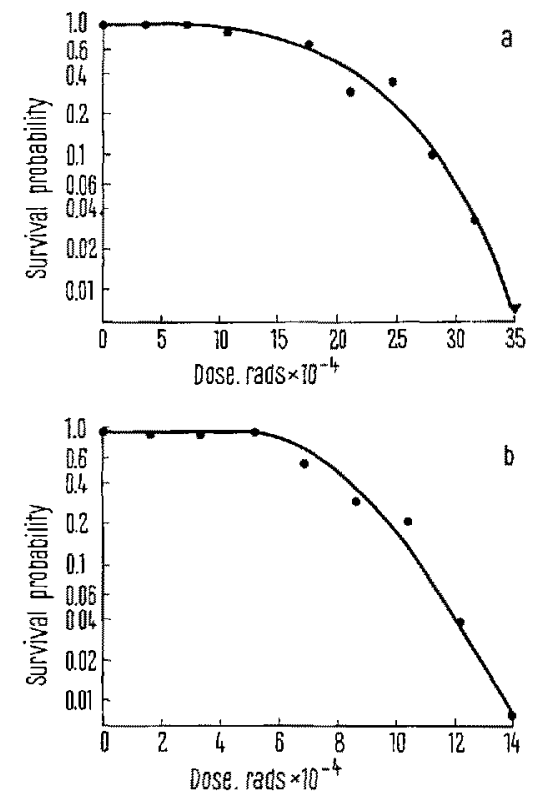

Fig. 1a, b. Survival probabilities of (a) Actinosphaerium mucleofilum and (b) Actinophyrs sol after various doses of ionizing radiation.
Results are presented graphically in Figures 1a, b and $2 a, b$. For either type of radiation the survival curve for both species can be made the same by a linear transformation along the abscissa. This suggests, as expected, that any particular radiation acts in the same manner on both species. However, whereas A. nucleofilum is 6 times as resistant to UV-light as $A$. sol, it is only $2^{1 / 2}$ times as resistant to ionizing radiation. (Dose rate effects ${ }^{6}$ may be ignored as they effectively cancel out in the 2 ratios.) This suggests directly what has previously been assumed, that ionizing radiation and UV-light act on different systems in the cell.
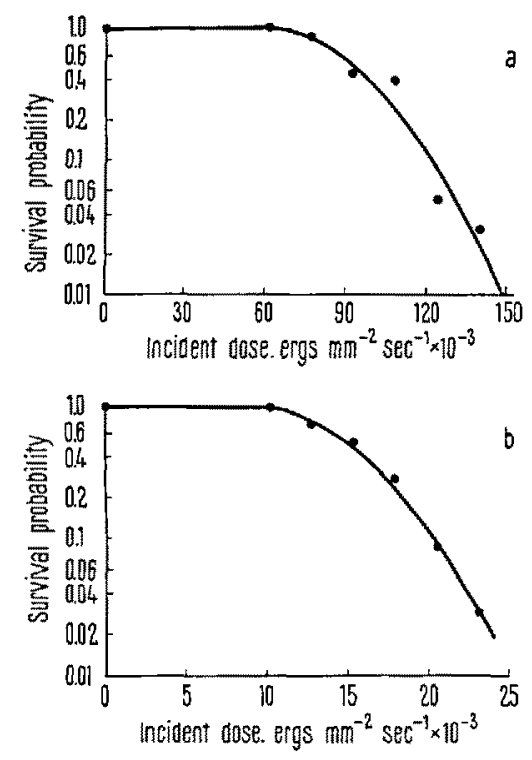

Fig. 2a, b. Survival probabilities of (a) Acinosphaerium nucleofilum and (b) Actinophrys sol after various doses of UV-light.

Résumté. Recherches sur l'effet des rayons UV et $\gamma$ chez 2 espèces très voisines de Protozoaires. D'après les résultats obtenus il semble probable que ces 2 rayons ont une action différente.

\section{S. A. Hodson ${ }^{7}$}

School of Biological Sciences, University of East Anglia, Norwich (Norfolk, U,K.), 24 July 1967.

1 E. W. Daniels, Ann. N.Y. Acad. Sci. 78, 662 (1959).

2 E. W. DANIELs and L. E. Rotw, Radiat. Res. 14, 66 (1961).

3 B. E. B. Mosetey and H. LAser, Nature 206,373 (1965).

- J. M. Barrett and D. M. Olinger, American Zoologist 1, 342 (1961).

s A. C. Giese, C. L. Brandt, R. M. Inverson and P. H. Welb, Biol. Bull. 103, 336 (1952).

6 L. C. Logie, M. D. Harris, R. E. Tatsch and E. N. VAN Hooser, Radiat. Res. 12, 349 (1960).

7 Present address: Department of Physiology, Institute of Ophthalmology, Judd Street, London, W.C.1. 